\title{
Measuring the Arab Parliament's institutional development
}

\author{
Mudher Abullraheem Abdulhameed \\ Department of Economics and Political Science, Cairo University, Giza, Egypt
}

\begin{abstract}
Purpose - This study aims to deal with the evaluation of institutional development and effectiveness of regional parliaments; it provides a scientific contribution to the development of the field of parliamentary studies by developing a set of indicators to present a parameter for evaluating regional parliaments with application to the Arab Parliament. The study concluded with the development of a parameter of 35 indicators to measure institutionally, efficiency and effectiveness of the institution, with application to the Arab Parliament, as well as developing an integrated assessment of the strengths and weaknesses in the institutional aspects and organizational efficiency.
\end{abstract}

Design/methodology/approach - The study is predicated on the principle of institutional approach and the systems analysis. The curriculum is applied to the Arab Parliament as an institution to quantify efficiency and efficacy according to the implementation of a set of proposed practical indicators. The study additionally applies both Huntington's institutional standards such as Adaptability, Involution, Autonomy and Coherence, as well as the indicators of institutions efficiency according to PrePanti such as Openness, Reception (R), Autonomy (A), Balance (B), Congruence (C), Internal Efficacy (I), Reformulation (R) and Roles (R), which refer to the first seven Latin letters "First RABCIRR".

Findings - The researcher endeavored to answer the main questions; How to quantify the degree of institutionalization, its impact on the efficiency and efficacy of regional parliaments. The researcher's approaches and the standards of efficiency and efficacy figured a comprehensive set of indicators that composed an integrated parliamentary standard to assess the degree of institutionalization, efficacy and efficiency of regional parliaments as a scientific contribution based on the Arab Parliament that can be applied to all regional parliaments.

Originality/value - This research is an attempt to create a Parliamentary Index to complement the previous scientific initiatives and efforts in developing such an index, which consists of 35 indicators and its application to the Arab Parliament. This research uses the principles of institutional approach, system analysis methodology and efficiency. The approach is applied to the Arab Parliament as a regional parliament to measure efficiency and effectiveness by applying a set of the proposed indicators.

Keywords Efficiency, Effectiveness, Institutionality, Arab Parliament, Parliamentary diplomacy, Regional parliaments

Paper type Research paper

\section{Introduction}

In light of the incrementing consequentiality of the parliamentary diplomacy exercised by regional parliaments in the presence of regional and international organizations, both in

(C) Mudher Abullraheem Abdulhameed. Published in Review of Economics and Political Science. Published by Emerald Publishing Limited. This article is published under the Creative Commons Attribution (CC BY 4.0) licence. Anyone may reproduce, distribute, translate and create derivative works of this article (for both commercial and non-commercial purposes), subject to full attribution to the original publication and authors. The full terms of this licence may be seen at http:// creativecommons.org/licences/by/4.0/legalcode

Received 3 June 2019 Revised 7 October 2019 Accepted 3 November 2019 
terms of presenting political visions, fortifying regional issues in international forums, and bringing the views of the conflicting parties proximate together. The paramountcy of proposing mechanisms, scientific and practical substrata for evaluating institutional developments and efficacy of regional parliaments, and its ability to achieve the goals for which it was engendered, and thus as one of the substrata of prosperous regional integration experiences.

The study of the Arab Parliament, which considers the legislative and supervisory institution of the Arab League, was established in 2005 on the substratum of the amendment of the Charter of the Arab League to become one of the main organs of the Arab League. The emergence of the Arab Parliament came in light of the political Movement witnessed in the Arab region, and the growing International pressure to move towards democracy. It has been an ephemeral parliament since 2005 until the Council of the League adopted its statutes as a perpetual parliament in 2012, in which members from all Arab countries are already members of their national parliament to represent the Arab people, not Arab regimes. The Arab Parliament is distinguished from Arab League organs that the voting system is a vote of individual members and not a vote of states or regimes. This gives parliament the specificity within the joint Arab working system as an implement for dialogue and decision and a popular impetus for the joint Arab action system, and an active partner in the formulation of the Prevalent Arab Policy, in the best fascinates of the Arab nation as a substratum for democratic development. Nevertheless, the Arab Parliament at the international level that it is still in the commencement that has not yet reached directly elected by the people.

The study examines the extent to which the Arab Parliament has been able to establish and develop organizational structures, within the Arab League framework, capable of carrying out the objectives for which it was established, to reach the efficacy that will avail it perform its functions in accordance with its statute and according to the literature of supranational regional organizations.

Consequently, the study seeks to build on previous scientific attempts to develop a scientific parameter for verifiable and quantifiable criteria for evaluating the efficiency, efficacy and development of regional parliaments predicated on the theory of organizations and the principles of the method of institutional analysis and efficiency of the institutional performance, and then apply them to the Arab Parliament, sanctioning the testing of this quantification and its indicators on any of the other regional parliaments.

\section{Research problem}

After parliaments have become a consequential factor in the international political life, which is quantified by their number or analysis of their influence or political presence, and the evolution of their traditional roles cognate to legislation and control of the executive power to incipient and non-traditional roles, in the convergence of peoples' nations through parliamentary diplomacy.

Since this development has been reflected in regional parliaments, this requires the Arab parliament to be examined as a modern Arab experience established within the framework of a regional organization, the Arab League, as has become regional parliaments such as parliaments. The European, the Parliamentary Assembly of Latin American and Caribbean States and the Pan-African Parliament.

Ergo, the research quandary revolves around a main question: 
Q1. Does the Arab Parliament have the constituents of the efficacious and efficacious regional parliament by quantifying the degree of institutionalization and its impact on its efficiency and efficacy?

Q2. Is it possible to build a parliamentary scale according to practical designators to assess the degree of institutionalization, efficacy and efficiency of regional parliaments in general?

\section{Importance of the research}

First, it presents a parliamentary index to complement anterior scientific initiatives and efforts. It consists of a set of practical indicators to assess the degree of institutionalization, efficacy and efficiency of the regional parliaments, and applying it on the Arab Parliament to be a pilot for other regional parliaments.

Second, the growing paramountcy of regional parliaments and the rapid change of their positions, which requires studying them in a scientific approach, in accordance with their role, efficiency and efficacy.

Third, studying some of the implements developed in the mechanisms of Arab joint action, represented by the Arab Parliament, which has not been subjected to rigorous academic scientific study afore.

Fourth, studying the institutional development of the regional parliamentary organization, through the values and determinants of this development, represents a good analytical material in the field of political science and parliamentary studies to study the impact of institutional development on the objective for which the organization was established, and then frame the substructure for the activation of regional parliaments by applying to the case study.

\section{Methodological framework}

The study is predicated on the principle of institutional approach and the system analysis. The curriculum is applied to the Arab Parliament as an institution to quantify efficiency and efficacy according to the implementation of a set of proposed practical indicators taking into account the Arab environment in which the Arab Parliament was established, and seeking to be an implement for activating the parent regional organization, the League of Arab States.

The study additionally applies both Huntington's institutional standards such as Adaptability, Involution, Autonomy, and Coherence. As well as the indicators of institutions efficiency according to PrePanti such as Openness, Reception (R), Autonomy (A), Balance (B), Congruence (C), Internal Efficacy (I), Reformulation (R), Roles (R), which refer to the first seven Latin letters "First RABCIRR".

\section{Institutional approach}

The study commences from the arguments of the institutional approach in its traditional and incipient form, which fixates on a number of aspects such as:

- Purpose of establishing an institution: any political institution is composed to achieve a concrete purport that should be verbally expressed in its objectives of establishment.

- The relative weight of the institution: it is the extent to which the institutions can influence States and international organizations to the extent of its powers. 
- The relationship with other institutions: is designated by the relationship with other nearby regional and international organizations. In light of international developments, it is inconceivable that an organization or institution should be established in isolation from the world around it as the relationship of international organizations to the circumventing environment indubitably affects the nature of the relationship to the issues they discuss and facilitates or impairs their performance.

- Institutional Adjustment: as institutions are subject to transmute to keep pace with the conditions and developments experienced by society, the extent to which the organization's systems respond to transmute in line with transmutations in the circumventing environment.

- The distribution of roles within institutions: the extent to which there is a distribution of roles within the organizations, and the extent of coordination of the distribution of tasks within the organization that affect the its final performance and its efficacy in political and international life in terms of specialization and integration.

In addition to the above verbalizations, and within the institutional framework, the researcher withal sought to use some of Samuel Huntington's conceptions on institution building and level of institutionalization.

\section{General framework}

Predicated on the above, the research is divided into three main components the following:

(1) establishment and development of the role of the Arab Parliament;

(2) implementation of efficacy indicators of regional parliaments on the Arab Parliament; and

(3) implementation of efficiency and institutional indicators on the Arab Parliament.

\section{Arab parliament origination, objectives and development}

The conception of establishing the Arab Parliament, as a popular representative institution within the framework of the League of Arab States, dates back to the mid-1950s. The League of Arab States submitted proposals in 1955 to amend its charter. This was the substructure for the subsequent decisions taken by the Arab summits on the establishment of the Arab Parliament, which was established by the summit of the Council of the League of Arab States (292) Held in Algiers, Republic of Algeria, on March 23, 2005. In this summit, several amendments were made to the Charter of the League of Arab States[1].

At the same summit, the Basic Law of the Arab Parliament was adopted, which stated in its first article that:

[... ] an Arab Parliament shall be established for a period of five years, which may be extended for a maximum period of two years, starting from the date of its first meeting.

Hence, the Transitional Arab Parliament started its work on 26 and 27 December 2005 (Hammad, 2004).

On March 28, 2010, the Council of the League of Arab States at the summit level issued Resolution No. 501 of the 22nd Mundane Session held in Sirte, which elongated the Transitional Arab Parliament for a period of two years to consummate the licit framework and the statute of the Perpetual Parliament. On March 29, 2012, the Council of the League of 
- "To be a space to practice the principles of shura, democracy, freedom and human rights", and to "be a space for practicing the principles of Shura, democracy, liberation and human rights".

- It is "tool for dialogue and decision and a popular impetus for the Arab action system, and an active partner in shaping prevalent Arab policy in the interest of the higher fascinates of the Arab nation. This affirms the principle of expanding political participation as a substratum for democratic development in the Arab countries to fortify the ties between the Arab peoples[2].

- The Arab Parliament consists of (88) members by the select of four members for each Arab country, taking into account women representation.

- National parliaments cull their members and aim to hold direct elections to cull members in the future.

- Follows the process of joint Arab action, by holding hearings or submitting inscribed questions to the heads of ministerial councils, the Secretary-General or the directors of specialized Arab organizations.

- The Arab parliament's indispensable approbation of Arab collective acquiescent and coalesced bills, while seeking harmonization and coordination between the Arab legislation in force.

- Cooperation with regional and international parliamentary organizations;

- Independence of the Arab Parliament in the approbation of its rules of procedure and its financial and administrative regulations.

- Arab Parliament relishes an independent fiscal budget, consisting of equal and binding annual quotas on the regimes of member states and approves its budget and final account annually.

- Legislative term is four years, divided into four convening roles, his bureau consisting of the President, four vice-presidents and the heads of the four standing committees are elected for a two-year term.

\section{Applying the indicators of efficacy of the regional parliaments to the Arab parliament}

Regional parliaments are one aspect of the development of parliamentary sodalities. They are the institutional way of exercising parliamentary diplomacy. They are exercised by parliamentarians by participating in parliamentary assemblies on a regional or continental substructure to raise the views of their peoples, as well as the pressure to direct regime policies to issues of cooperation and co-subsistence, and veneration for the collective intrigues of peoples. These meetings provide an opportunity for dialogue to resolve issues that may not be addressed through formal channels and contribute to the engenderment of an international public opinion on sundry issues of concern to society (Inter-Parliamentary Union, 2000).

There are two distinct forms of international parliamentary organizations; first, parliamentary organizations in the form of a federal parliamentary coalescence, that is, member states have merged with each other and forsook part of their sovereignty to 
engender a amalgamated political entity such as the European Coalescence, represented by the European Parliament. It is the Parliament of Supra-National[3]. It is the unique situation in the modern world. The denizens of the member states of the European Cumulation are directly represented, and are relatively geographically composed. The number of seats in each country varies according to the population standard of each country. Second; Parliamentary organizations in the form of a Confederation of Parliamentary Cumulation, an organization comprising independent sovereign members, the national parliaments of member states of an international political or strategic organization, composing a transnational inter-parliamentary amalgamation, parity or differences in population size, through parliamentary divisions and delegations representing national parliaments holistically. Examples include:

- Inter-Parliamentary Union;

- Arab Inter-Parliamentary Union; and

- Parliamentary Union of the Organization of the Islamic Conference Members.

Some parliamentary sodalities include parliaments of states allied on a political substratum, such as the Inter-American Parliamentary Coalescence of the Organization of American States, or a strategic one, such as the NATO Parliamentary Assembly of the Atlantic Treaty Organization, or on an economic substructure such as the InterParliamentary Forum, And the Parliamentary Conference of Presiding Officers of euroMediterranean Parliaments.

The real importance of regional parliaments as representative or parliamentary bodies within international or regional political systems lies in their essence for integrative or collaborative relationships, historical experiences substantiate this, such as[4]:

- successful experiences of economic integration culminating in the establishment of a parliamentary entity, evidenced by the coal and steel group that ended up in the European Amalgamation, and within it the European Parliament;

- successful political integration experiences culminate in the establishment of a parliamentary wing, such as the Inter-Parliamentary Cumulation of North American States, as well as the NATO Parliamentary Organization; and

- the parliamentary umbrella has become a central objective in regional organizations such as the GCC, the Consultative Body, the Organization of African Unity (OAU), and the African Amalgamation.

Toward building a quantification to assess the efficacy of regional parliaments

There is no doubt that the conception of evaluating the efficacy of the most alluring and modern endeavors, building a quantification to assess the efficacy designates:

First, taking into account the dimensions of the situation in question and the aspects of the subject under evaluation, in a comprehensive and precise manner, so that their variations and situations can be adequately relegated.

Second, the essence of a concrete value system lies in the purport of the evaluation itself, and determines the degrees and quality of the scale, negatively and positively.

Third, the quantification process fixates on the most paramount aspects and dimensions that are indicative of the state of the subject of quantification. 
Determinately, the scale applies only to ostensible things, which can already be quantified utilizing a number of indicators. In other words, the parameter generally refers to the state of the object or phenomenon in question, and puts it on the congruous scale in the quantification system, reveals the extent of change that occurs (Al-Sawy, 2003b).

\section{The applied system: evaluating the efficacy of regional parliaments}

The quantification adopted by the researcher to evaluate the efficacy of regional parliaments consists of 31 indicators, relegated into five major groups, as well as four incipient indicators that can be reviewed and applied to the Arab Parliament as follows:

\section{Policy indicators}

Indicators for the establishment and objectives.

Indicator 1: specificity privacy of inchoation.

Whenever regional parliaments are engendered "concretely" to achieve parliamentary objectives such as; representation, legislation and oversight, that will avail them to consummate their work, while they arise as a sub-component or "accompaniment" of other political or specialized processes, economic cooperation or coordination in peregrine policy. The more likely the parliamentary goals are to be delayed in favor of the emergence of non-parliamentary objectives (Al-Rashidi, 1997) (Tables I, II and III).

According to indicator (1), the Arab Parliament was established by virtue of the decision of the Council of the League of Arab States at summit level No. 292 of 23 March 2005. Arab Parliament shall be established, where its composition, functions and terms of reference are mentioned in to its statute". This system aims to engender "a space for the practice of the principles of consultation, democracy, liberation and human rights[5]".

Indicator 2: pellucidity of objectives. The quantification units are the extent to which the objectives are defined, the degree of their scope or their applicability. There has been widespread interest in the consequentiality of crystallizing and formulating goals after the

\begin{tabular}{|c|c|c|c|c|c|c|}
\hline \multirow{2}{*}{$\frac{\text { No. }}{1}$} & \multirow{2}{*}{$\frac{\text { Indicator }}{\text { Establishment }}$} & \multicolumn{4}{|c|}{ Scope } & \\
\hline & & $\begin{array}{l}\text { Independent and } \\
\text { authentic }\end{array}$ & $\begin{array}{l}\text { Responding to } \\
\text { pressures }\end{array}$ & Transitional & Integration & \\
\hline 2 & Objectives & Specific and clear & Multiple & General & Mysterious & Table I. \\
\hline 3 & $\begin{array}{l}\text { Relationship } \\
\text { with executive } \\
\text { organizations }\end{array}$ & Independent & $\begin{array}{l}\text { Watching and } \\
\text { cooperating with them }\end{array}$ & Advisory & Follower & $\begin{array}{r}\text { Indicators for the } \\
\text { establishment and } \\
\text { objectives }\end{array}$ \\
\hline
\end{tabular}

\begin{tabular}{|c|c|c|c|c|c|c|}
\hline No. & Indicator & Start & $(+)$ & $\begin{array}{l}\text { Scope } \\
\text { End }\end{array}$ & $(-)$ & \\
\hline 4 & Responsibilities & Graduated & Clear & Consultancy & $\begin{array}{l}\text { General and } \\
\text { unrealistic }\end{array}$ & \\
\hline 5 & $\begin{array}{l}\text { Parliamentary } \\
\text { Nature }\end{array}$ & Legislative & $\begin{array}{l}\text { Legislative and } \\
\text { Oversight }\end{array}$ & Consultancy & $\begin{array}{l}\text { Political and } \\
\text { technical }\end{array}$ & \\
\hline 6 & $\begin{array}{l}\text { Mandatory } \\
\text { decisions and } \\
\text { Recommendations }\end{array}$ & Guided & Obligatory & $\begin{array}{l}\text { Recommendations for } \\
\text { consideration }\end{array}$ & $\begin{array}{l}\text { Non-binding } \\
\text { recommendations }\end{array}$ & $\begin{array}{r}\text { Table II. } \\
\text { Terms of references } \\
\text { and powers }\end{array}$ \\
\hline
\end{tabular}




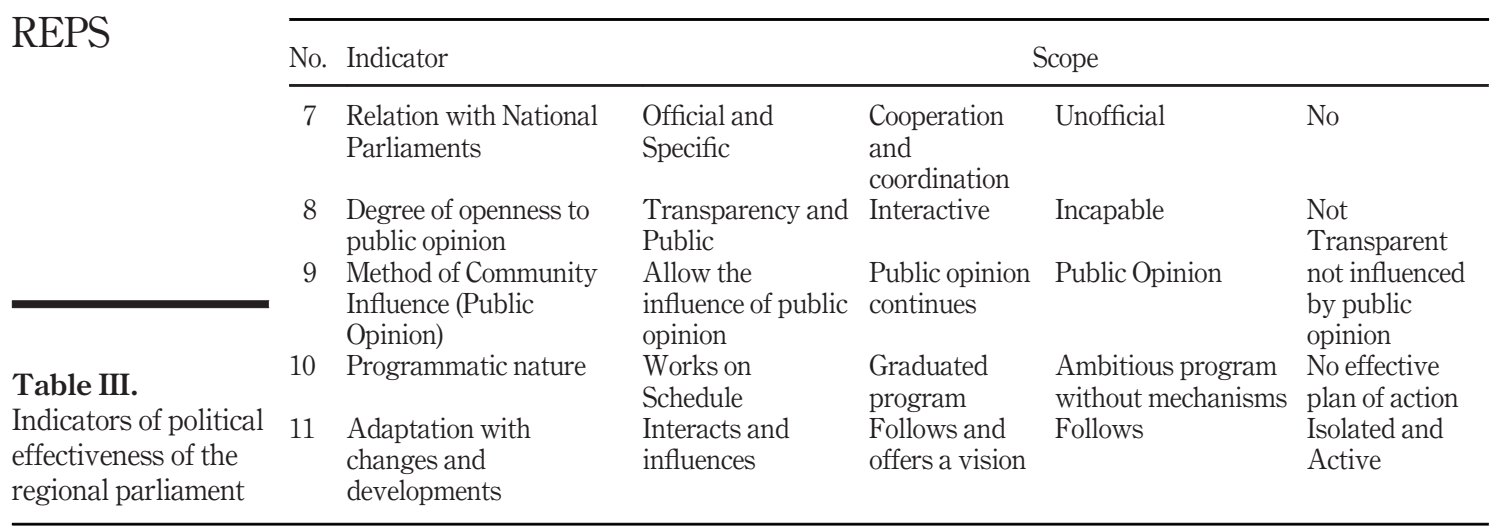

spread of Management by Objectives. Consequently, the objectives were compulsory to facilitate the sundry activities in the organization, without which orchestrating becomes nonessential (Afendi and Rashid, 1995). The most paramount of which are: pellucidity and definition, realism and legitimacy, measurability. Consequently, by applying to the Arab Parliament, its objectives are broad without concrete and clear procedures or phased objectives to be evaluated and moving on to the next goal. Hence, Law of the Arab Parliament, and in accordance with Article II of its Rules of Procedure, the Parliament shall achieve the following objectives ${ }^{2}$ :

- establishing an Arab system for practicing the principles of consultation (Shurah), democracy, liberation and human rights, and engendering a comprehensive framework for the representation of the denizens of the one Arab nation;

- participating actively in the formulation of joint Arab policies and the establishment of an integrated Arab system that achieves convivial equity, faces challenges and promotes developments in the Arab nation; and

- creating vigilance among the Arab peoples of the joint Arab action and contributing to enhancing security, tranquility and stability in the Arab region.

Indicator 3: relationship with governmental organizations (regional). The performance of the regional parliament, its organs and members cannot be implemented without the acquiescent on the areas of coordination and cooperation between it and the executive branch within the regional organization, and identifying channels and denotes through which the desired cooperation can be achieved. This enables the Regional Parliament to exercise its competencies and powers efficaciously. Sundry regional parliamentary experiences have always referred to a variety of debates and acquiescent to achieve cooperation and coordination between the Regional Parliament and the Executive one (Al-Munufi, 2004).

With the application of the Arab Parliament, it is still an advisory body. In fact, the Arab summit in Kuwait in March 2014 corroborated the consultative role of the parliament[6].

Indicator 4: resoluteness and nature of competence. Whenever the mandate and functions of the Regional Parliament are pellucid and concrete, they have been active in their role, and the more facile their performance.

By applying this on the Arab Parliament, Article \#5 of the statute declared its powers and terms of reference. It was general and loose without clear procedures, and 
did not designate the mechanisms of implementation, which led to the conclusion of a mechanism to regulate the relationship between the Arab Parliament and the Secretariat of the League of Arab States, to enable parliament to play its role. Article\# 5 of the terms of reference of Parliament withal states that; "The Parliament exercises its powers to promote joint Arab action, and achieve economic integration, convivial solidarity and sustainable development, leading to the achievement of Arab unity, especially the following points:

- to invigorate the Arab-Arab cognations and develop the forms of joint Arab action and fortify its mechanisms;

- follow-up the joint Arab action and hold hearings with the heads of the ministerial councils or the Secretary-General of the League or the heads or general directors of the specialized Arab organizations;

- discuss the matters referred to it by the Council of the League, the Ministerial Councils, the Secretary-General of the League or the heads or directors of specialized Arab organizations;

- address questions in indicating to the heads of the Ministerial Councils, the Secretary-General of the League and to the directors of the specialized Arab organizations;

- approval of draft amalgamated laws and collective Arab acquiescent referred to him afore being approved by the League;

- consider budget projects and final accounts of the General Secretariat of the League afore being approved by the competent ascendant entities, as well as the final accounts of the specialized Arab organizations; and

- harmonize and coordinate between the laws in force in Member States in preparation for their cumulation and the exchange of legislative experiences between national parliaments[7].

Indicator 5: parliamentary nature. The more regional parliaments with technical or political competence, it becomes homogeneous to other international and regional organizations, as well as the absence of representation, and thus losing part of their distinctiveness.

By applying to the Arab Parliament, articles (4-15) of the rules of procedure of the Parliament set forth rules and procedures for the exercise of its powers and powers provided for in article \#5 of its Statute, which are still binding and make it consultative. These available methods exercise the potencies of the Parliament and include the following:

- Draft coalesced laws and collective Arab acquiescent referred to Parliament by the Arab League and its specialized organizations.

- Proposals for the cumulation of laws submitted by members of the Arab Parliament or one of its perpetual committees.

- Written parliamentary questions directed by members of the Arab Parliament to the heads of the Ministerial Councils, the Secretary-General of the League and the heads and directors of all its specialized organizations.

- Hearings held by the Parliament with the heads of the Ministerial Councils, the Secretary-General of the League or the heads or directors of all the specialized Arab organizations. 
Indicator 6: the extent to which outputs are obligatory. The more decisions are obligatory, the more preponderant the capacity of regional parliaments, as well as their validity.

In reviewing the functions of the Arab Parliament, it is pellucid that what its issues is recommendations; consequently, it is not binding. It withal raises its opinion to the Arab Ministerial Council or Summit, including recommendations as a substructure for discussion rather than a decision. Article 5 of the Statute states the following:

- to discuss the issues referred to it by the Council of the League, the Ministerial Councils, the Secretary General of the League or the heads or directors of the specialized Arab organizations, and to give an opinion thereon, and may make recommendations thereon; and

- to approbate draft coalesced laws and collective Arab accedences referred to him and afore being approved by the Council League.

Indicators of political efficacy of the regional parliament. The political efficacy of the parliament is quantified by institutionalizing the cognations with national parliaments, activating the performance of the regional parliament and coordinating with it, especially in terms of standardizing legislation or endeavoring to exchange experiences among countries, and its facility to acclimate to changes and developments in the internal and external environment.

Indicator 7: relationship with national parliaments. The relationship between the Arab Parliament, Arab National Parliaments is varied and different; there is no mechanism for cooperation or binding different parties' protocol; hence the relationship varies from country to country. Thus, it does not play an influential or coordinating role with national parliaments and councils.

Indicator 8: the degree of openness to public opinion. One of the most consequential manifestations of transparency and openness is the openness to denizens and national and regional civil society organizations, in addition to granting observer status to international organizations to monitor the performance of Parliament.

As for the Arab Parliament, all parliamentary sessions are broadcast directly through television channels and are available to all. The sessions are held at the League of Arab States headquarters, but the parliament still lacks some efforts to influence public opinion and the Arab street.

Indicator 9: impact of society and public opinion. The Arab Parliament needs an exigent need to develop communication with public opinion and denizens in the Arab world, sanctioning for mutual influence with public opinion or soi-disant systems approach to feedback.

Indicator 10: programmatic nature of objectives. To what extent were the objectives of the regional parliaments time-bound and consistent with the circumstances circumventing them, as well as the orchestration for the parliamentary organizations whether they were concrete or not, and all these factors affect their performance (Clark, 1969).

Article 86 of the Rules of Procedure of the Arab Parliament requires the preparation of an annual program of work every session, which must be approved by the Bureau of Parliament. An annual program of work is already prepared for each session.

Indicator 11: adaptation to changes and developments. The extent to which the regional parliament is able to develop roles and programs acclimated to the transmuting environment and regional and international challenges. The Arab Parliament is endeavoring to acclimate to the circumventing changes and is endeavoring to respond to them. There are endeavors to enter into a public and parliamentary perspective on a number 
of issues. It has worked to develop some committees to keep abreast of regional and international developments such as the establishment of a committee on human rights in the Arab world.

\section{Membership indicators}

Indicator 12: nature of membership.

The parliamentary system is one of the pillars of representative democracy, depending on a number of Members of the Parliament, who exercise the function of expressing popular will in the political, convivial and economic life (Theodore and Salmon, 1995). Membership of the Arab Parliament is composed of national parliaments from through nominations of 22 Arab countries' national parliaments. Each country culls a number of (4) members, at least one of them women, without designating the method of testing, and ergo the members of the Arab Parliament are not directly elected denizens, and the way they are culled varies from country to country, it may be through internal elections in the national parliament, or through Parliamentary division, or requests from members, or a cull of the presidency or Bureau of parliament for membership of the Arab Parliament ${ }^{2}$ (Table IV).

Indicator 13: term of membership. Legislative term of the Arab Parliament is four years, but the membership of the Arab Parliament shall remain in force until after the expiration of the legislative term, unless his country appoints another member.

Indicator 14: number of seats allocated to member states. Arab Parliament adopted the equalization of seats allocated to each Member State of Parliament. This does not reflect the relative weight of the population of each country because the Arab parliament is not an elected parliament.

Indicator 15: conditions of membership. There are no requisites or requisites for membership of the Arab Parliament, other than the requisite that the Member of the Arab Parliament be essentially a member of its national parliament only, and consequently there is a diversity in the composition of the Arab Parliament in terms of age, Education level, method of election or appointment to the national parliament, Political and party affiliation. The restriction on membership was not to amalgamate an Arab member of parliament with an executive position in his country, and if a member held an executive or judicial position in his state, his membership would culminate.

\begin{tabular}{|c|c|c|c|c|c|c|}
\hline No. & Indicator & Start & $(+)$ & $\begin{array}{l}\text { Scope } \\
\text { End }\end{array}$ & $(-)$ & \\
\hline 12 & $\begin{array}{l}\text { Nature of } \\
\text { Membership }\end{array}$ & $\begin{array}{l}\text { Direct } \\
\text { Elections }\end{array}$ & Indirect Elections & $\begin{array}{l}\text { Nomination of } \\
\text { parliamentary blocs }\end{array}$ & Appointment of States & \\
\hline 13 & $\begin{array}{l}\text { Duration of } \\
\text { Membership }\end{array}$ & Specific & $\begin{array}{l}\text { Independent of the } \\
\text { National Parliament }\end{array}$ & $\begin{array}{l}\text { Continuing after the } \\
\text { dissolution of the } \\
\text { national parliament }\end{array}$ & $\begin{array}{l}\text { Linked to the } \\
\text { membership of the } \\
\text { National Parliament }\end{array}$ & \\
\hline 14 & Number of Seats & $\begin{array}{l}\text { By } \\
\text { demographic } \\
\text { weight }\end{array}$ & $\begin{array}{l}\text { According to the } \\
\text { political weight }\end{array}$ & By Area & $\begin{array}{l}\text { Equal seats for } \\
\text { parliaments }\end{array}$ & \\
\hline 15 & $\begin{array}{l}\text { Conditions of } \\
\text { Membership }\end{array}$ & & Private & & $\begin{array}{l}\text { terms of the National } \\
\text { Parliament }\end{array}$ & \\
\hline 16 & $\begin{array}{l}\text { Discharged of } \\
\text { Membership }\end{array}$ & Total & & artial & Non-membership & Table IV. \\
\hline 17 & $\begin{array}{l}\text { Immunities and } \\
\text { privileges }\end{array}$ & & Private & & Nationality & $\begin{array}{r}\text { Membership } \\
\text { indicators }\end{array}$ \\
\hline
\end{tabular}


Indicator 16: full time degree of MP. The statute of the Arab Parliament sanctioned the cumulation of its membership and that of the National Parliament, and ergo the members are not part-time for the work of the Arab Parliament, and the extent of interest and active participation among the members varies, where the interest in the National Parliament prevails over the interest in the Arab Parliament.

Indicator 17: membership immunities and privileges. The Member of the Arab Parliament relishes objective immunity for his opinions and does not hold these opinions accountable after the terminus of his membership, as well as judicial immunity, and applies to members of the Arab Parliament the accedence of privileges and immunities of the Arab League, and diplomatic immunities at the headquarters of parliament in the state Syria, this gave the Member of Parliament a high degree of stability and liberation of expression.

Financial jurisdiction and stability of the regional parliament Indicator 18: financial competence of the regional parliament.

The Rudimental Law of the Arab Parliament pointed out that the Parliament has the right to consider the budget of the League of Arab States and its specialized organizations as well as its final accounts. This has not been applied on the ground (Table V).

Indicator 19: method of budgeting for the Arab parliament according to its statutes. Arab Parliament is independent in setting its budget and defining it, but there is a dilemma regarding the incrimination of these contributions or the exemption of some of them.

Indicator 20: the degree of financial resources stability. Arab Parliament's financial resources are the main source of States contributions to the annual budget of the Parliament; it suffers from non-commitment to pay contributions to its budget, and these desiderata to be reviewed especially after the transition to Parliament Lasting after a seven- year transitional parliament (Bourqaba, 2006).

\section{Indicators for the institutional structure}

\section{Indicator 21: the method of surmising the presidency for the Arab parliament.}

President shall be elected by direct secret ballot among members of the Parliament and in accordance with its internal rules of Parliament by a simple majority. Election term shall be two years for each of the President and his four Vice Presidents and the Chairmen of the Committees. This period is renewable only once and this gives a quantification of instauration of elites within the Arab Parliament (Table VI).

Indicator 22: election of the committee's offices. For the Arab Parliament, the Chairman and Vice-Chairman of the Committee shall be elected by secret ballot among the members of the Parliament and in accordance with its internal rules, by a simple majority of members.

Table V.

Financial jurisdiction and stability of the regional parliament

\begin{tabular}{|c|c|c|c|c|c|}
\hline No. & Indicator & & Scope & & \\
\hline 18 & Financial Jurisdiction & $\begin{array}{l}\text { Approves the budget } \\
\text { of the Executive } \\
\text { Organization }\end{array}$ & Review the budget & $\begin{array}{l}\text { Looking forward to } \\
\text { the budget }\end{array}$ & No role \\
\hline 19 & Method of budgeting & Set the budget & $\begin{array}{l}\text { Set by the executive } \\
\text { Branch }\end{array}$ & $\begin{array}{l}\text { Set by higher } \\
\text { authority }\end{array}$ & $\begin{array}{l}\text { Does not } \\
\text { affect its } \\
\text { budgeting }\end{array}$ \\
\hline 20 & $\begin{array}{l}\text { Stability of Financial } \\
\text { Resources }\end{array}$ & Stable & Renewable & & Unstable \\
\hline
\end{tabular}




\begin{tabular}{|c|c|c|c|c|c|c|}
\hline No. & Indicator & Start & $(+)$ & $\begin{array}{l}\text { cope } \\
\text { End }\end{array}$ & $(-)$ & \multirow{4}{*}{$\begin{array}{r}\text { Arab } \\
\text { Parliament's } \\
\text { institutional } \\
\text { development }\end{array}$} \\
\hline 21 & Presidency & Direct Election & Indirect Election & Appointment & \multirow{2}{*}{$\begin{array}{l}\text { Periodic } \\
\text { Rotation } \\
\text { Periodic } \\
\text { Rotation }\end{array}$} & \\
\hline 22 & $\begin{array}{l}\text { Choose/elect } \\
\text { Committees } \\
\text { offices }\end{array}$ & Direct Election & Indirect Election & Appointment & & \\
\hline 23 & No of Standing & objectives & Variable according & Fixed according to the & Do not & \\
\hline 24 & $\begin{array}{l}\text { session } \\
\text { Periodicity }\end{array}$ & $\begin{array}{l}\text { Continuous and } \\
\text { permanent } \\
\text { sessions }\end{array}$ & $\begin{array}{l}\text { To subjects } \\
\text { Periodical Sessions }\end{array}$ & $\begin{array}{l}\text { number of mempers } \\
\text { Seasonal Sessions }\end{array}$ & $\begin{array}{l}\text { express goals } \\
\text { Non- } \\
\text { periodical } \\
\text { Sessions }\end{array}$ & \multirow{2}{*}{$\begin{array}{r}\text { Table VI. } \\
\text { Indicators for the } \\
\text { institutional } \\
\text { structure }\end{array}$} \\
\hline 25 & Voting Weight & \multicolumn{2}{|c|}{ Individual Voting } & \multicolumn{2}{|l|}{ National Block } & \\
\hline
\end{tabular}

Indicator 23: number of standing committees. In cognation to the Arab Parliament (the rules of procedure set forth in its article 25 the number of committees as follows:

- Committee on Peregrine Cognations, Politics and National Security;

- Committee for Economic and Financial Affairs;

- Committee on Legislative, Licit and Human Rights Affairs; and

- Committee on Gregarious, Scholastic and Cultural Affairs, Women and Youth. It already covers all the objectives of the Parliament verbally expressed in its Statute.

Indicator 24: periodicity parliamentary session. Arab Parliament is divided into legislative chapters of for years each, and holds at least 5 sessions each legislative year, ergo there is periodicity and regularity in the meetings of Parliament.

Indicator 25: voting weights. Individual Voting for each member of the Arab Parliament without Countries interference

Technical and administrative regulatory indicators

Set of indicators for parliamentary work organization.

Indicator 26: degree of coordination and integration between internal organs.

Bureau is responsible for the organization and management of parliament's affairs and facilities and its organs, and in the case of the Arab Parliament, there is great coordination between the Office and the Secretariat as the President of the Arab Parliament is the supervisor of the work of the Secretariat, and heads the Bureau meetings concurrently (Table VII).

\begin{tabular}{|c|c|c|c|c|c|c|}
\hline No. & Indicator & Start & $(+)$ & $\begin{array}{l}\text { Scope } \\
\text { End }\end{array}$ & $(-)$ & \\
\hline 26 & $\begin{array}{l}\text { Coordination between } \\
\text { internal organs }\end{array}$ & High & Gradual & Seasonal & $\begin{array}{l}\text { Lack of coordination } \\
\text { and integration }\end{array}$ & Table VII. \\
\hline 27 & Setting the agenda & Consultation & The office & Chairman & Technical & Set of indicators for \\
\hline 28 & Nature of Discussions & Parliamentary & Consultancy & Political Discussion & $\begin{array}{l}\text { Governmental } \\
\text { Discussions }\end{array}$ & $\begin{array}{l}\text { the organization of } \\
\text { parliamentary work }\end{array}$ \\
\hline
\end{tabular}


Indicator 27: method of setting the agenda. The Bureau of the Parliament composed of the President, four deputies and four chairmen of the four committees draw up the agenda of the meetings and sessions, taking into account the suggestions of the committees and its members. That is the way the agenda is set in consultative rather than authoritarian or technical.

Indicator 28: nature of internal debates. Albeit parliamentary debates are held by a system and issue non-binding recommendations that give further study and examination of many views; until decisions or recommendations are reached, and there are multiple stages until the decision is reached, while sundry committees have a central role in preparing for discussions in the plenary.

\section{Indicators of the secretariat}

Indicator 29: method of selecting the secretary general of the Arab parliament.

The Secretary General is selected by the Bureau after receiving nominations from member states and receiving their candidates. Bureau selects one of the candidates, and put it to vote in Parliament session, and is selected by a majority for a one-time instauration only, and the same applies to Assistant Secretaries-General (Table VIII).

Indicator 30: selecting staff. Secretariat, in any international organization, either regional or ecumenical, is of great consequentiality, given the nature of the Secretary-General's position in particular within the regulatory framework of the organization. This is indicative of the relationship of the Secretary-General to Member States in Parliament in general (Shaaban, 1985).

Indicator 31: the nature of the headquarters. Sempiternal headquarters of Arab Parliament is in Syria and the transitory one is in Egypt. However, the Arab Parliament may meet in any Member State at the invitation of this State.

The researcher integrates to the indicators above some indicators that avail to study the integrated regional parliaments through the following indicators:

Indicator 32: vision and role indicator. The Parliament's facility to formulate a clear vision represents a program of action to activate its terms of reference and crystallize the objective through which it engendered. The vision reflects the political will to establish this regional parliament and represents the authentic impetus for action. This vision and momentum must emanate from the priorities of denizens' issues in countries.

Indicator 33: facility to develop the roles. This is done through programs habituated to transmute in the circumventing environment and regional and international challenges, and to respond to the requisites of international authenticity, and the faculty to assemble homogeneous regional parliaments, and to cooperate with international and regional parliamentary sodalities and organizations.

This indicator represents a challenge for the Arab Parliament, especially in view of the homogeneous attributes of roles and the conflict of powers and functions between it and the

Table VIII.

Indicators of the secretariat

\begin{tabular}{llllll}
\hline & & \multicolumn{3}{c}{ Scope } & \\
No. & Indicator & Start & $(+)$ & End & $(-)$ \\
\hline 29 & $\begin{array}{l}\text { Selection of } \\
\text { Secretary-General }\end{array}$ & Elected & Indirect election & $\begin{array}{l}\text { Appointed by } \\
\text { chairman/Bureau }\end{array}$ & Appointed \\
30 & $\begin{array}{l}\text { Selection of the } \\
\text { staff }\end{array}$ & Efficiency & $\begin{array}{l}\text { Exams and } \\
\text { Fessions }\end{array}$ & From host country & $\begin{array}{l}\text { National } \\
\text { quotas }\end{array}$ \\
& $\begin{array}{l}\text { Nature of the } \\
\text { Location }\end{array}$ & Private and stable & $\begin{array}{l}\text { Temporary and } \\
\text { unstable }\end{array}$ & $\begin{array}{l}\text { Alternating } \\
\text { between States }\end{array}$ & $\begin{array}{l}\text { Lack of } \\
\text { premises }\end{array}$ \\
\hline
\end{tabular}


Arab Parliamentary Amalgamation. It is identically tantamount situation in the conflict between the Pan-African Parliament and the African Parliamentary Cumulation.

Indicator 34: structure of the secretariat. Intricacy and composition within the Secretariat of the Parliament as a management wing with well ancillary of the political wing, and to what extent there is a fit between the structure of the parliament and the structure of the executive body, which is the case of the Arab parliament in the League of Arab States, its Secretariat, its Ministerial Councils and its specialized Arab organizations.

Indicator 35: administrative and non-hierarchical series. To what extent there is an approved administrative structure of the Parliament capable of translating goals and functions efficaciously, and the extent to which the Secretariat relishes institutional aspects through the existence of working manuals and a description of the competence of departments and units within the Arab Parliament, In integration to the extent to which the Secretariat has the technical expertise of researchers and experts to provide technical support, studies, papers and research to avail the decision maker and to develop possible alternatives in front of him efficaciously.

\section{Efficiency and efficacy indicators in the application to the Arab parliament}

The Bryanti and Huntington Index is one of the most prominent benchmarks by which a high degree of institutionalization can be achieved within institutions in international organizations. In this context, it is consequential to quantify the extent to which these indicators are available to the institutional standards in the Arab Parliament.

In this context, the applicability of Bryanti seven indicators could be quantified and is referred to in the first seven letters RABCIRR and Huntington's four institutional indicators. The study seeks to coalesce the two components together as follows:

\section{First: degree of openness, acceptance of incipient, and adaptation}

This indicator applies to the institutional and performance frameworks of parliament in several ways as the Arab Parliament seeks to corroborate the degree of transparency and openness to Arab denizens, and to achieve a degree of institutional adjustment through several designates, including:

- Publicity of the sessions of the Arab Parliament and broadcast live through media and audio-visual. The average number of meetings and sessions of the Arab Parliament in accordance with the bespeakers of the first legislative quarter (20122016) is 22 meetings, and his office (46) held meetings, as well as its four standing committees (82) meetings.

- Follow-up of the Arab Parliament to the process of joint Arab action, and hold hearings with the heads of the Ministerial Council or the Secretary General of the League, or the presidents or directors of specialized Arab organizations, through public sessions that discussed very consequential topics (Arab national security, the human rights situation in The Arab world, sustainable development, the Arab strategic framework and its operational agenda, priorities for joint Arab action in the light of Arab summit resolutions, obstacles to Arab economic integration, human development, and women's empowerment priorities).

- Use Arab Parliament web site, information technology, and convivial communication to be open to the Arab denizens.

- Arab Parliament perpetuates communication with the Arab community through its events such as seminars, conferences and workshops. 
This indicator applies to the institutional framework of the Arab Parliament in several points as follows:

The independence of setting systems. Article 5 of the Statute affirms the substructure of ascertaining the independence of Arab Parliament by adopting and amending its rules of procedure, approving its budget and final accounts, approving and amending its financial and administrative regulations and its capability to amend it.

Article 20 of the Statute assures the independence of the Arab Parliament's budget. It verbally expresses that "the Parliament shall have an independent annual budget prepared by its General Secretariat in accordance with the financial and accounting principles and submitted to the Bureau for review afore being approved by the Parliament.

Immunity of member of the Arab parliament. Member of the Parliament shall relish parliamentary immunity to ascertain its independence. Article 9 of the Statute of the Parliament stipulates that "A Member of Parliament shall never be queried about the views they expressed in the course of his/her functions."

\section{Third: balance index}

This indicator applies to institutional frameworks in several ways, Where the Arab Parliament, according to its statute, is considered the legislative and regulatory institution of the League of Arab States, and an active partner in setting the joint Arab policy. The Arab Parliament plays an incrementing role on a number of issues, including issues cognate to the Arab-Israeli conflict, the relationship with major powers such as the Cumulated States of America, issues of democracy and human rights, Arab-Arab reconciliations, economic and trade cooperation between Arab states, and other issues in an endeavor to find the required balance between formal work and popular action through the provisions of its statutes, which are the following:

- Addressing inscribed questions to the heads of the Ministerial Councils, the Secretary-General of the League, and to the directors of the specialized Arab organizations, and they shall answer the questions of the members within a concrete duration as designated by the rules of procedure; and

- Consideration of budget projects and final accounts of the General Secretariat of the League afore its approbation by the competent ascendant entities, as well as the audit of the final accounts of specialized Arab organizations.

\section{Fourth: roles identification index}

The Statute of the Arab Parliament affirmed its functions and potencies, albeit they were not categorically defined and quantified to promote joint Arab work, and achieve economic integration, convivial solidarity and sustainable development by:

Promote Arab-Arab cognations, develop joint Arab action, fortify its mechanisms, ascertain Arab national security, promote human rights, make recommendations and proposals that deems felicitous:

- discuss issues referred to it by the Arab League, the Ministerial Councils, the Secretary General of the League, and heads or directors of the specialized Arab organization;

- ask indited questions to the heads of the Ministerial Councils, the Secretary-General of the Arab League; 
- approbe draft coalesced laws and collective Arab accedences referred to it afore being approved by the Council of the Arab League;

- consider draft budgets and final accounts of the General Secretariat of the Arab League, as well as the audit of the final accounts of specialized Arab organizations;

- harmonize and coordinate among laws in force in Member States, in preparation for their cumulation and the exchange of legislative experiences among national parliaments;

- cooperate and coordinate with national parliaments in Member States to promote and consolidate the popular dimension and its role in the process of joint Arab action; and

- cooperate with regional and international parliamentary organizations to accommodate the intrigues of the Arab nation and maintain international tranquility and security.

\section{Conclusion}

The researcher endeavored through the three axes of this research paper to answer the main research questions; first, how to quantify the degree of institutionalization and its impact on the efficiency and efficacy of regional parliaments by applying it to the Arab Parliament; second, if it is possible to build a parliamentary scale predicated on practical indicators to assess the degree of institutionalization, efficacy and efficiency of the regional parliaments in general.

Through the researcher's approaches and the standards of efficiency and efficacy he tested, he drew up a comprehensive set of applied indicators that composed an integrated parliamentary standard to assess the degree of institutionalization, efficacy and efficiency of regional parliaments as a scientific contribution, and was applied to the Arab Parliament as a regional parliament, and can be applied to the rest of other regional parliaments, and concluded, and the research reached the following results:

- The dilemma of the role and powers of the Arab Parliament because of the lack of vision pellucidity, either when it was established as a regional parliament because of differences on powers and roles on the one hand, and the consequentiality of the presence of Arab councils on the other hand; as it still plays advisory role in some Arab countries, others lack the capacity and mechanisms to balance with the executive branch. It is withal noted that the potencies of the Arab Parliament came loose without precise definition of mechanisms and implements of work.

- The adherence of full sovereignty of States is an obstruction to the activation of the Arab Parliament, which plays a consultative non-binding role, and its indicators on the equal number of parliamentary members representing each country regardless of the proportional representation of the population in each country.

- The inability of Arab Parliament to set and develop roles, especially in light of nature of membership of the Arab Parliament, where it is composed by designating members from countries and not by direct elections, in addition to the homogeneous roles and conflicts of powers and functions between the Arab Parliament and the Arab Parliamentary Cumulation.

- Albeit the presence of the Arab Parliament is a paramount step toward achieving the Arab strategic objectives in promoting Arab solidarity and establishing the desired Arab unity, the developments in the Arab political, economic and cultural 
aspects, as well as the international changes that reflect their influence on the Arab region, made the mission of Arab parliament not facile.

- Through the implementation of the institutional development indicators, it turns out that the Arab parliament theoretically relishes a degree of institutional efficacy, but virtually lacks it. This showed the evolution in job performance and gradualism in the activation of its statute. It additionally showed the tribulations to assess performance to develop it through the transition to a permanent parliament, while the role of the parliament is still non-binding advisory role.

- Despite the fact that the Arab Parliament has achieved a tangible performance in theory since its inception by contributing to the joint Arab action, through its conferences and activities, and its openness to public opinion and public meetings, and broadcast live on Arab television. However, these activities do not issue binding resolutions, but only recommendations through which the Arab Parliament, as a non-elected parliament from all Arab peoples, toward what is transpiring on the Arab and ecumenical scene. However, the Arab Parliament is considered to have made a consequential contribution toward activating the role of Arab parliamentary diplomacy and institutionalizing cognations with kindred parliaments such as the Pan-African Parliament and the Latin American and Caribbean Parliament through the conclusion of joint acquiescent and memorandums of understanding, in integration to the adoption by the InterParliamentary Coalescence of the proposal of the Arab Parliament to establish the Coordinating Council of Presiding Officers of Regional Parliaments.

\section{Recommendations}

By applying the parliamentary standards adopted by the study on the Arab Parliament so that it can play its role to the fullest extent requires a set of recommendations to be achieved. The Arab Parliament will prosper in playing an efficacious role as a regional parliament in representing Arab public opinion and activating joint Arab action. These recommendations are given next.

\section{First: recommendations cognate to the circumventing environment of the Arab parliament}

- The consolidation of democracy in the Arab world, as the vigor of the Arab Parliament is a reflection of the vigor of Arab national parliaments. This requires the provision of licit guarantees to ascertain liberation of opinion, and the independence of these parliaments.

- Crystallizing the role of the Arab Parliament in the Arab League as the legislative body, and the popular force of joint Arab action, by addressing the institutional shortcomings and the low caliber of efficacy and efficiency by reviewing the terms of reference.

- Pursuing the progressive application of the mechanism of selecting members of the Arab Parliament to direct elections in accordance with its statutes. However, the first phase could be through indirect elections within the Arab national parliaments to select their representatives in the Arab parliament.

Second: recommendations for the work of the parliament

Regarding the definition of substantive framework governing the work of parliament.

- Quantification adopted by the study stressed the paramountcy of the openness of the parliament to public opinion, and the authentic mutual influence between 
parliament and Arab society, which should be represented in authentic representation and not in the form of a visual representation of the cumulated legislative policy and its cultural, And dealing with it as a national cultural wealth must be represented and maintained.

- Consultation among Member States to reach consensus on their disposition to waive part of their legislative powers in favor of the Arab Parliament.

- Harmonization of national and regional legislative situations to eschew conflict, so that the transformation of the Arab parliament into a legislative ascendancy is not a formality that does not integrate value to the process of integration and efficacious role.

At the procedural level. Predicated on the appliedlthat have been tested on the Arab Parliament, a set of amendments should be put in place to expedite the transition from the consultative role to the legislative role with full legislative powers by:

- expedite the step of composing the Arab Parliament according to proportional representation of the population in member states in lieu of distributing seats equally; this will avail in finding a well representative parliament of all political affiliations;

- institutionalize the relationship with the executive bodies in the League of Arab States, through a mechanism for coordination and cooperation and activate the role of each; and

- institutionalize the relationship with national parliaments, especially in the area of standardization of legislations and exchange of legislative experiences.

\section{Notes}

1. The resolutions of the Algiers Summit are published on the official website of the League of Arab States at: www.lasportal.org/en/summits/Pages/default.aspx?Stype=1\&imgLib=ArabicSummit\& $\mathrm{RID}=41$

2. The Statute of the Arab Parliament is published on the official website of the Arab Parliament at: https://ar-pr.org/

3. The IPU website is available at: www.ipu.org

4. Ahmed Sayed Ahmed, so that the Arab Parliament is the locomotive of the joint action, the media observatory, available at the following link: http://statecouncil.om/portal/marsadfile.asp?id=55

5. Resolution of the Council of the League of Arab States at Summit Level No. (559) issued by the 23rd Ordinary Session held in Baghdad, Republic of Iraq.

6. The resolutions of the Kuwait Summit 2014, published on the League of Arab States website at: www.lasportal.org/en/summits/Pages/default.aspx?Stype=1\&imgLib=ArabicSummit\&RID=41

7. Statute of the Arab Parliament, a former source.

\section{References}

Afendi, A.H. and Rashid, A. (1995), Introduction of the Department, Dar al-Nahda al-Arabiya, Cairo.

Al-Munufi, K. (2004), The Origins of Comparative Political Systems, Al-Rabian Publishing and Distribution, Future, Series knowledge, Kuwait, Politics Press, Kuwait. 
Al-Rashidi, A. (Ed.) (1997), "Introduction”, The Legislative Establishment in the Arab World, Center for Research and Political Studies, Cairo University, Cairo.

Al-Sawy, A. (2003b), Measuring the Effectiveness of Parliament, Cairo.

Bourqaba, I. (2006), "The transitional Arab Parliament after democracy in the joint Arab action system, Algeria”, Journal of Parliamentary Thought, National Assembly of Algeria, No. 11.

Clark, J.V. (1969), “A healthy organization”, in Bennis, W.G., et al. (Eds), The Planning of Change, Hott, Rinehart, New York, NY.

Hammad, M. (2004), League of Arab States, Introduction to the Future, Dar Al-Maarefah Series, Politics Press, Kuwait.

Inter-Parliamentary Union (2000), Secretariat of the Inter-Parliamentary Union, Inter-Parliamentary Union, Geneva.

Shaaban, S. (1985), "Roles and functions of the general secretariat of the league of Arab states", Arab Affairs, No. (41), March 1985.

Theodore, C.L. and Salmon, C.T. (Eds) (1995), Public Opinion and the Communication of Consent, The Guilford Press, London.

\section{Websites}

The Basic Law of the Arab Parliament Published On the official website of the Arab Parliament at: https://ar-pr.org/

The Rules of Procedure of the Arab Parliament, published in The official website of the Arab Parliament on the link: https://ar-pr.org/

\section{Further reading}

Afendi, A.H. (1991), Center for Research and Political Studies, Administrative Organization of the International Organization, Cairo.

Ahmed, K. and Razek, A. (2004), "Measuring the performance of international parliamentary unions, applied to the European parliament and Arab parliamentary union", Master Thesis, Faculty of Economics and Political Science, Cairo University, Unpublished.

Ahmed, K. and Abdel Razek, A. (2015), Measuring the Performance of International Parliamentary Associations, Applying to the Arab Parliament, Cairo, Afaq Afriqia, The State Information Service, April 16, 2015.

Al-Ghaithi, J.A.Y. (2006), "Policy making in regional and international organizations, applied study on the league of arab states", Master Thesis, Sadat Academy for Administrative Sciences, Cairo.

Al-Rashidi, A. (2001), Revitalization of the Arab Regional System, Faculty of Economics and Political Science, Cairo.

Al-Sawy, A., (Translator) (2003a), European Parliament, Corbett, R., et al. (Eds), Center for Parliamentary Studies, Faculty of Economics and Political Science, Cairo University, Cairo.

Baaklini, A., Denoeux, G.P. and Springborg, R. (1999), The Resurgence of Parliamentary Politics in the A rab World, Lynne Rienner Publishers, London.

Group of Authors (2014), A rab League Future Vision, Hammad, M. (Ed.) Institute of Arab Research and Studies, Cairo.

Huntington, S.P. (1971), "Political development and political decay", in Welch, C.E. (Ed.) Political Modernization - A Reader in Comparative Political Change, Wadsworth, Belmont, CA.

Mowafi, A.M. (1985), "Council of the league of arab states", Ph.D., Faculty of Economics and Political Science, Cairo.

Rashad Al-Qasabi, A.G. (2008), Institutional and Institution Building, Series of Political Development Publications, Kingdom of Bahrain. 
Selim, M.E.S. (1993), The Effectiveness of the Organization of the International Islamic Conference, Evaluation Study, International Politics, Al-Ahram Foundation.

Shalaby, I. (1992), International Organization of International, Regional and Specialized Organizations, University House, Cairo.

Yahya, E.A. (2012), Cairo, Institute of Arab Research and Studies.

Arab

Parliament's institutional development

\section{Corresponding author}

Mudher Abullraheem Abdulhameed can be contacted at: alrawi2008@yahoo.com

For instructions on how to order reprints of this article, please visit our website: www.emeraldgrouppublishing.com/licensing/reprints.htm Or contact us for further details: permissions@emeraldinsight.com 